\title{
Production and biochemical responses of cowpea under thermal and water stress
}

\author{
Juliane Rafaele Alves Barros ${ }^{1} \odot$, Miguel Júlio Machado Guimarães ${ }^{\circledR}$, Rodrigo Moura e Silva ${ }^{3}$, \\ Welson Lima Simões ${ }^{4}$, Natoniel Franklin Melo ${ }^{4}$, Francislene Angelotti ${ }^{4 *}(\mathbb{0}$ \\ ${ }^{1}$ Universidade Estadual de Feira de Santana, Feira de Santana, BA, Brasil. E-mail: juliane-ab@hotmail.com \\ ${ }^{2}$ Instituto Federal de Educação, Ciência e Tecnologia do Maranhão, São Raimundo das Mangabeiras, MA, Brasil. E-mail: miguel.guimaraes@ifma.edu.br \\ 3 Universidade de Pernambuco, Petrolina, Brasil. E-mail: moura.pnz@gmail.com \\ ${ }^{4}$ Embrapa Semiárido, Petrolina, PE, Brasil. E-mail: welson.simoes@embrapa.br; natoniel.melo@embrapa.br; francislene.angelott@embrapa.br
}

ABSTRACT: Water deficit and high temperature limit agricultural productivity, affecting plant growth, development, and metabolism. Thus, the objective of this study was to evaluate the impact of the interaction between water deficit and temperature increase on cowpea production. The experiment was carried out with the cultivar BRS Rouxinol, in growth chambers, in a $4 \times 2$ factorial arrangement, being four soil water availability $\left(25 ; 50 ; 75\right.$ and $100 \%$ of field capacity) and two daily temperature regimes $\left(\mathrm{T}^{\circ} 1\right.$ : 20-26-33 ${ }^{\circ} \mathrm{C}$ and $\mathrm{T}^{\circ} 2: 24.8-30.8-37.8^{\circ} \mathrm{C}$ ). The increase in water availability favored an increase in shoot and root dry mass. The vegetative stage was prolonged in plants maintained at a temperature regime of $24.8-30.8-37.8^{\circ} \mathrm{C}$. The cowpea yield increased with higher water availability. The water availability of $90 \%$ was the one that provided the highest water use efficiency. The $4.8^{\circ} \mathrm{C}$ increase in air temperature promotes an increase in oxidative stress with lack of synchrony in the antioxidative defense system. The cultivar Rouxinol is sensitive to the increase in air temperature and water deficit. However, even with $100 \%$ water availability, there was no seed production with an increase in air temperature.

Key words: abiotic stress; heat stress; grain yield; oxidative stress; Vigna unguiculate

\section{Produção e respostas bioquímicas de feijão-caupi sob estresse térmico e hídrico}

RESUMO: O déficit hídrico e a alta temperatura limitam a produtividade agrícola, afetando o crescimento, o desenvolvimento e o metabolismo das plantas. Assim, o objetivo deste estudo foi avaliar o impacto da interação entre déficit hídrico e aumento de temperatura na produção de feijão-caupi. O experimento foi realizado com a cultivar BRS Rouxinol, em câmaras de crescimento, em arranjo fatorial $4 \times 2$, sendo quatro a disponibilidade de água no solo $(25 ; 50 ; 75$ e $100 \%$ da capacidade máxima de retenção de água) e dois regimes de temperatura $\left(\mathrm{T}^{\circ} 1: 20-26-33^{\circ} \mathrm{C}\right.$ e $\left.\mathrm{T}^{\circ} 2: 24,8-30,8-37,8^{\circ} \mathrm{C}\right)$. $\mathrm{O}$ aumento da disponibilidade de água favoreceu 0 aumento da massa seca da parte aérea e da raiz. A fase vegetativa foi prolongada em plantas mantidas em regime de temperatura de $24,8-30,8-37,8^{\circ} \mathrm{C}$. $\mathrm{O}$ rendimento do feijão-caupi aumentou com a maior disponibilidade de água. A disponibilidade de água de $90 \%$ foi a que proporcionou a maior eficiência no uso da água. $\mathrm{O}$ aumento de $4,8^{\circ} \mathrm{C}$ na temperatura do ar promove um aumento no estresse oxidativo com falta de sincronia no sistema de defesa antioxidante. A cultivar Rouxinol é sensível ao aumento da temperatura do ar e ao déficit hídrico. Entretanto, mesmo com 100\% da disponibilidade hídrica não houve produção de sementes, com o aumento da temperatura do ar.

Palavras-chave: estresse abiótico; estresse por calor; produção de grãos; estresse oxidativo; Vigna unguiculada

\footnotetext{
* Francislene Angelotti - E-mail: francislene.angelotti@embrapa.br (Corresponding author)

Associate Editor: Mário de Andrade Lira Júnior
} 


\section{Introduction}

The constant change in environmental conditions exposes plants to water deficit and high temperatures (Jumrani \& Bhatia, 2018). With climate change, these two elements will become limiting for crop productivity (Fahad et al., 2017), affecting plants at the molecular, morphological and physiological level, compromising plant growth, metabolism and development (Gray \& Brady, 2016).

In recent years, extreme weather events have become more frequent, showing greater intensity and duration (Cunha et al., 2019). Climate forecasts indicate an increase of up to $4.8^{\circ} \mathrm{C}$ for the end of the century, with changes in the rain regime, with prolonged droughts (IPCC, 2013). These drought events generate a great vulnerability to the semi-arid region, showing that this region will be strongly affected by the impacts of climate changes (IPCC, 2013).

Consequently, agricultural production will be significantly affected, since photosynthesis, is highly sensitive to temperature increase and water deficit (Hatfield, et al., 2011). The interaction of these stresses may reduce photosynthetic activity, promote stomata closure and increase leaf temperature (Perdomo et al., 2015), inhibiting plant growth and reducing crop yield (Ndiso et al., 2016). These stresses also cause an increase in the accumulation of reactive oxygen species (ROS), which cause damage to cells and the death of plants (Toscano et al., 2016).

However, the impact of these abiotic stresses depends on the duration, intensity and the phenological stage during its occurrence. Thus, plants can respond through different defense mechanisms (Merwad et al., 2018), such as the production of antioxidant enzymes: superoxide dismutase, catalase, ascorbate peroxidase and glutathione peroxidase (Toscano et al., 2016). In cowpea (Vigna unguiculata L), Carvalho et al. (2019), observed an overproduction of ROS in plants under water deficit. In response, there was an increase in the activity of the SOD and APX enzymes (Carvalho et al., 2019) and catalase (Merwad et al., 2018).

As a legume, particularly characterized by adaptation in semi-arid regions, cowpea is considered a key crop in the context of global climate change and food security (Carvalho et al., 2019). It is important for human and animal food as a cheap source of protein, in addition to generating employment and income for small growers (Merwad et al., 2018).

Studies with cowpea show the response of plants submitted to a single condition of abiotic stress. However, in the field, the interaction of abiotic stresses occurs concurrently, and elucidating this impact is a strategic issue for food security. Thus, the objective of this research was to evaluate the impact of the interaction between the water deficit and temperature increase on cowpea production and biochemical responses.

\section{Materials and Methods}

The experiment was conducted in growth chambers Fitotron type, with temperature, humidity and photoperiod control. The study was conducted from August 2018 to February 2019. Cowpea seeds of the cultivar BRS Rouxinol were used, planted in 7 pots in a $4 \times 2$ factorial arrangement, considering four levels of soil water availability (25; 50; 75 and $100 \%$ of field capacity) and two daily temperature regimes: $\mathrm{T}^{\circ} 1$ : $20-26-33{ }^{\circ} \mathrm{C}\left(20^{\circ} \mathrm{C}\right.$ : between $8 \mathrm{pm}$ and $6 \mathrm{am}$; $26^{\circ} \mathrm{C}$ : between 6 a.m. and 10 a.m. and $33^{\circ} \mathrm{C}$ : from 10 a.m. to 3 p.m.; $26^{\circ} \mathrm{C}$ : from 3 p.m. to 8 p.m.); $\mathrm{T}^{\circ} 2: 24.8-30.8-37.8$ ${ }^{\circ} \mathrm{C}\left(24.8{ }^{\circ} \mathrm{C}\right.$ : between 8 p.m. and 6 a.m.; $30.8^{\circ} \mathrm{C}$ : between 6 a.m. and 10 a.m.; $37.8^{\circ} \mathrm{C}$ : from 10 a.m. to 3 p.m.; $30.8^{\circ} \mathrm{C}$ : from 3 p.m. to 8 p.m.), with four repetitions. The temperature values were determined from the minimum, average and maximum temperatures ranging from 18-22, 25-27 and 32-34 ${ }^{\circ} \mathrm{C}$, respectively, in the semiarid. The increase of $4.8{ }^{\circ} \mathrm{C}$ was used according to the IPCC scenario for the end of the century.

For irrigation management, weighing lysimeters were installed in all vessels, equipped with load cells (model TSD, $\mathrm{AEPH}$, with a capacity of $50 \mathrm{~kg}$ ) installed under a metal base with a device for collecting the excess of drained water. Fertilization was carried out two days before planting, according to the results of the soil chemical analysis and the crop recommendation (Cavalcanti, 2008). The irrigation was carried out every other day with the aid of the data generated by the lysimeters, in which the volume of the evapotranspirated water was replaced to maintain the soil water availability for each treatment.

\section{Determination of the phenological cycle}

During the experiment conduction, daily assessments of the plants phenological stage were carried out, divided into two phases: vegetative and reproductive. The vegetative phase was divided into: V0 - Germination; V1 - Emergency; V2 - Primary leaves; V3 First open composite leaves; V4 - Third open trifoliate leaves. The reproductive phase was be divided into: R5 - Pre-flowering; R6 - Flowering; R7 - Pod formation; R8 - Filling of pods; and R9 - Maturation (Oliveira et al., 2018)

\section{Productive and biometric parameters}

The evaluation of shoot dry mass (SDM) and root dry mass (RDM) was carried out after the harvest, by cutting the stem close to the soil to separate shoots and roots. The materials were packed in paper bags and kept in an oven at 65 o $\mathrm{C}$ until reaching constant weight $( \pm 72 \mathrm{~h}$ ). After this period, the dry weight was obtained using a digital scale.

To assess the flowers abortion (starting at stage R6), the flowers of each plant were daily counted and the number of aborted flowers was obtained.

The seed production and the primary components were evaluated: number of seeds per plant and seeds weight to assess production data. These evaluations were carried out when the plants reached the pod maturation stage.

\section{Water use efficiency}

The water use efficiency $\left(\mathrm{g} \mathrm{L}^{-1}\right)$ was calculated with the relation of seed production $(\mathrm{g})$ by the amount of water used in irrigation during the entire cycle. 


\section{Enzymatic activity determination}

Leaf sampling for biochemical analysis was performed 30 days after planting. Green and fully expanded leaves without injuries, located in the middle third of the plant were collected. The samples were immediately stored in aluminum foil envelopes and immersed in liquid nitrogen $\left(\mathrm{NL}_{2}\right)$. Extracts were prepared using $1 \mathrm{~g}$ of leaf material macerated in liquid nitrogen with the addition of $0.01 \mathrm{~g}$ of polyvinylpolypyrrolidone and $3 \mathrm{~mL}$ of extraction buffer $(\mathrm{pH} 7.5)$ at a concentration of 100 $\mathrm{mM}$ potassium phosphate. Then, the extract was centrifuged at $15,000 \mathrm{~g}$ for 15 minutes, at $4{ }^{\circ} \mathrm{C}$, and the supernatant was used as a crude enzyme extract.

The catalase activity (CAT) was determined following the decomposition of $\mathrm{H}_{2} \mathrm{O}_{2}$ for 60 seconds, by reading on a spectrophotometer at $240 \mathrm{~nm}$ and temperature of $25{ }^{\circ} \mathrm{C}$, according to the method described by Havir et al. (1987). The ascorbate peroxidase (APX) activity was determined as described by Nakano \& Asada (1981), by monitoring the oxidation rate of ascorbate, using a spectrophotometer with a wavelength at $290 \mathrm{~nm}$, at $25^{\circ} \mathrm{C}$, for 60 seconds. The determination of the guaiacol peroxidase (GPX) enzyme was determined, followed the method developed by Cakmak \& Horst (1991), monitoring the reduction of guaiacol in a spectrophotometer with a wavelength at $470 \mathrm{~nm}$, at $25^{\circ} \mathrm{C}$, for 60 seconds. The activity of superoxide dismutase (SOD) was determined according to Giannopolitis \& Ries (1977), at a wavelength of $560 \mathrm{~nm}$, and defining the SOD unit as the amount of enzyme needed to inhibit NBT photoreduction by $50 \%$.

\section{Statistical analysis}

The results were submitted to variance analysis with the application of the $\mathrm{F}$ test $(\mathrm{p}<0.05)$, and a regression analysis was performed in the presence of a significant effect for the water amount and interactions, using the software SISVAR Version 5.6. The averages obtained were compared by regression analysis.

\section{Results and Discussion}

The interaction of water availability $\mathrm{x}$ temperature was significant for root dry mass of cowpea plants, but the shoot dry mass was not affected by the cited interaction (Table 1). It was observed the isolated effect of water availability and temperature increase on root and shoot dry mass weight (Table 1).

It can be observed a linear increase on shoot dry mass with an increase in water availability, regardless the temperature (Figure 1A). For root dry mass, a linear behavior is also observed according to the temperature regimes (Figure $1 \mathrm{~B})$. The greater the water availability, the greater the root dry mass (Figure $1 \mathrm{~B}$ ). However, the regime with higher air temperature lead to a reduction of $31.73 \mathrm{~g}$ in root dry mass in plants under full irrigation (100\%), when compared to the temperature of $20-26-33{ }^{\circ} \mathrm{C}$ (Figure 1B). The increased temperature in the root zone has a direct impact on root
Table 1. Summary of variance analysis using the mean square for the parameters shoot and root dry mass of cowpea plants, cultivar Rouxinol, according to water availability and temperature regime in Brazil, 2018.

\begin{tabular}{lccc}
\hline \multirow{2}{*}{$\begin{array}{l}\text { Variation } \\
\text { source }\end{array}$} & \multirow{2}{*}{ DF } & \multicolumn{2}{c}{ MS } \\
\cline { 3 - 4 } & & SDM & RDM \\
\hline Water availability (WA) & 3 & $1549.22^{* *}$ & $7160.82^{* *}$ \\
Temperature (T) & 1 & $239.9^{* *}$ & $426.10^{* *}$ \\
WA $\times$ T & 3 & $88.14^{\text {ns }}$ & $530.61^{* *}$ \\
Residue & 24 & 33.98 & 42.61 \\
CV\% & & 24.88 & 18.06 \\
\hline
\end{tabular}

$\mathrm{DF}=$ degree of freedom; $\mathrm{CV}=$ coeficient of variation; $\mathrm{ns}=$ not signifficant, ${ }^{* *}$ significant at $1 \%$ of probability, according to Tukey's test.
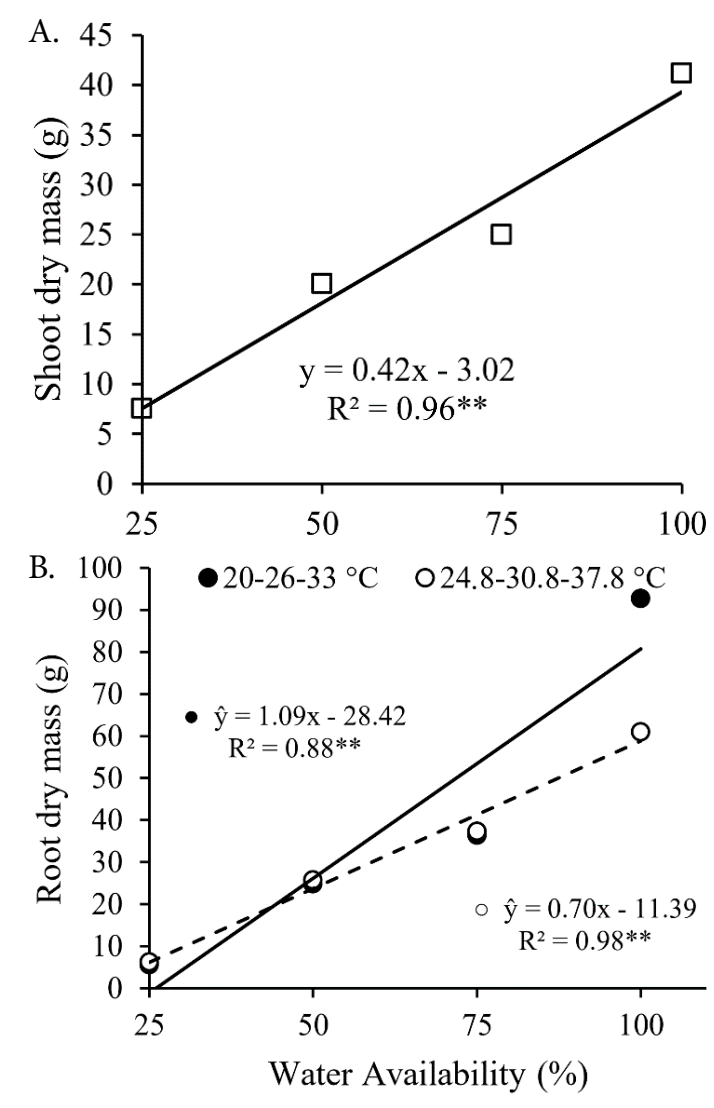

Regression coeficient significant with $\mathrm{p}<0.01\left(^{* *}\right)$.

Figure 1. Shoot and root dry mass (g) of cowpea plants cultivar Rouxinol accoding to water availability.

development, affecting the absorption and transport of water and nutrients (Koevoets et al., 2016). In addition, the increase in temperature results in changes in the carbon balance, reducing the ratio of the concentrations of $\mathrm{CO}_{2}$ and $\mathrm{O}_{2}$ and favoring oxigenativa activity of Rubisco. This process increases photorespiration and reduces photosynthesis, compromising plant growth and development, with a consequent reduction in biomass (Martinez et al., 2015). When soil water availability is below the field capacity, the plants reallocate the resources from the shoots to the roots, interrupting the growth. The reduced shoot growth is a plant physiological response, causing a decrease in water loss due to transpiration (Gray \& Brady, 2016). The prolonged water deficit causes a decline in leaf water potential and in the opening stomatal, reducing leaf 
size and decreasing root growth (Xu et al., 2016). According to Gray \& Brady (2016), the development of the root system can be directly affected by elevated soil temperatures, or indirectly, by changes in the plant physiology.

The number of days of each phenological stage and the duration of the cycle of the cultivar Rouxinol are shown in Table 2. The stages V0 and V1 lasted from 1 to 2 days in the different water availability and in the two temperature regimes.

The $4.8{ }^{\circ} \mathrm{C}$ increase in air temperature, with availability of 50,75 and $100 \%$ water, reduced the stages V2 and V3 and prolonged the stage V4. (Table 2). Similar results were observed by Angelotti et al. (2020), where the high temperature also prolonged the vegetative stage of cowpea plants from cultivar BRS Pujante and resulted in flowers abortion. According to Hatfield et al. (2011), the length of the vegetative phase may increase with increasing temperature, up to an ideal point, specific to each crop. Upon reaching this point, growth and development slow and eventually stop. A similar result was observed in the present study, where plants kept under increased temperature associated with lower water availability did not formed flower buds, stage R5 (Table 2). This occurred because the water deficit can decrease the rate of inflorescence development or lead to partial or complete inhibition of flowering, since the development of male and female floral organs are highly vulnerable to increased temperature and water deficit (Gray \& Brady 2016).

Plants kept at $20-26-33{ }^{\circ} \mathrm{C}$ and $25 \%$ of water availability showed an increase of more than 20 days in cycle duration (Table 2). However, despite the increase in days, all plants completed the cycle in this temperature regime. In plants maintained at a temperature of $24.8-30.8-37.8{ }^{\circ} \mathrm{C}$ this was not observed. It is noted that, even with high water availability, the plants were not able to close the cycle, because the increase of $4.8^{\circ} \mathrm{C}$ in the air temperature, caused a drastic reduction or no formation of the floral bud, in addition to the abortion of floral bud and pods formation (Table 2). The combination of high temperature and low water availability can slow or inhibit the development of flower buds, resulting in fewer flowers and causing a substantial reduction in cowpea production (Ndiso et al., 2016).

The results obtained for the variable production confirm the negative effect of the increase in air temperature. With the low number of flower buds formed and the flowers abortion, it was not observed the pods production, as previously reported. Therefore, only the average data in the regression analysis of plant production at a temperature of 20$26-33{ }^{\circ} \mathrm{C}$ will be presented. In cowpea, night temperature of $30{ }^{\circ} \mathrm{C}$ decreases the viability of pollen grains and indehiscent anthers, increasing the flower abortion and affecting the final pod retention (Freire Filho et al., 2005). The higher night air temperatures increase flower abscission, reducing grain yield (Nielsen \& Hall 1985). This could be a problem in semi-arid regions in the future climate scenario, requiring the evaluation of cultivars tolerant to high temperatures during the flowering period.

The water availability also affects the cowpea number of seeds. The increase in water availability result in an increase in the number of seeds per plant (Figure 2A). When irrigated with 100,75 and $50 \%$ of field capacity, the average number of seeds was 211, 162.8 and 61.3, respectively. This is because water is a limiting factor for seeds quality and production of several species with agronomic potential (Fahad et al., 2017), including cowpea.

The water availability of 75 and $100 \%$ resulted in the production of 28.14 and $41.57 \mathrm{~g}$ of seeds to plant, respectively (Figure 2 B). As water availability increases, the crop express better its productive potential, since water is a limiting factor for production (Mwale et al., 2017). It is observed that when the water availability is reduced, the production was lower, with 1.295 and $14.72 \mathrm{~g}$, respectively with 25 and $50 \%$ of irrigation (Figure $2 \mathrm{~B}$ ).

The reduction in seed production under water stress is associated with a decrease in production components, such as the number of pods per plant and the number of seeds per pod. Cowpea is sensitive to water stress in the flowering and pod filling stages, causing flower abortion, pod dropping and reduced seed filling (Mwale et al., 2017).

Regarding the water use efficiency (WUE), is observed a quadratic behavior with the increase in soil water availability (Figure $2 \mathrm{C}$ ). The $90 \%$ of water provided the most efficient water use, with $1.13 \mathrm{~g} \mathrm{~L}^{-1}$. In this way, it can be said that the best water/ grain conversion point occurs when plants are submitted to $90 \%$ of water availability. From this value there is a reduction in efficiency, indicating that when irrigation approaches optimum

Table 2. Number of days for each phenological stage and duration of the cowpea cycle, cultivar Rouxinol, according to water availability and temperature regime.

\begin{tabular}{|c|c|c|c|c|c|c|c|c|c|c|c|c|}
\hline \multirow{2}{*}{ Temperature } & \multirow{2}{*}{$\begin{array}{c}\text { Water } \\
\text { availability (\%) }\end{array}$} & \multicolumn{10}{|c|}{ Phenological cycle(days) } & \multirow{2}{*}{ Cycle } \\
\hline & & Vo & V1 & V2 & V3 & V4 & R5 & R6 & R7 & R8 & R9 & \\
\hline \multirow{3}{*}{$20-26-33^{\circ} \mathrm{C}$} & 25 & 1 & 2 & 8 & 14 & 61 & 2 & 2 & 14 & 2 & 2 & 108 \\
\hline & 50 & 2 & 2 & 7 & 9 & 37 & 2 & 1 & 15 & 3 & 6 & 84 \\
\hline & 100 & 2 & 2 & 7 & 5 & 37 & 2 & 1 & 16 & 2 & 7 & 81 \\
\hline \multirow{2}{*}{$24.8-30.8-37.8^{\circ} \mathrm{C}$} & 25 & 2 & 2 & 6 & 23 & 60 & - & - & - & - & - & 93 \\
\hline & 100 & 1 & 2 & 5 & 2 & 45 & 1 & 2 & 11 & - & - & 69 \\
\hline
\end{tabular}

V0 - Germination; V1 - Emergence; V2 - Primary leaves; V3 - First open composite leave; V4 - Third open trifoliate leave; R5 - Pre-flowering; R6 - Flowering; R7 - Pod formation; R8 - Pods filling; R9 - Pods maturation. 

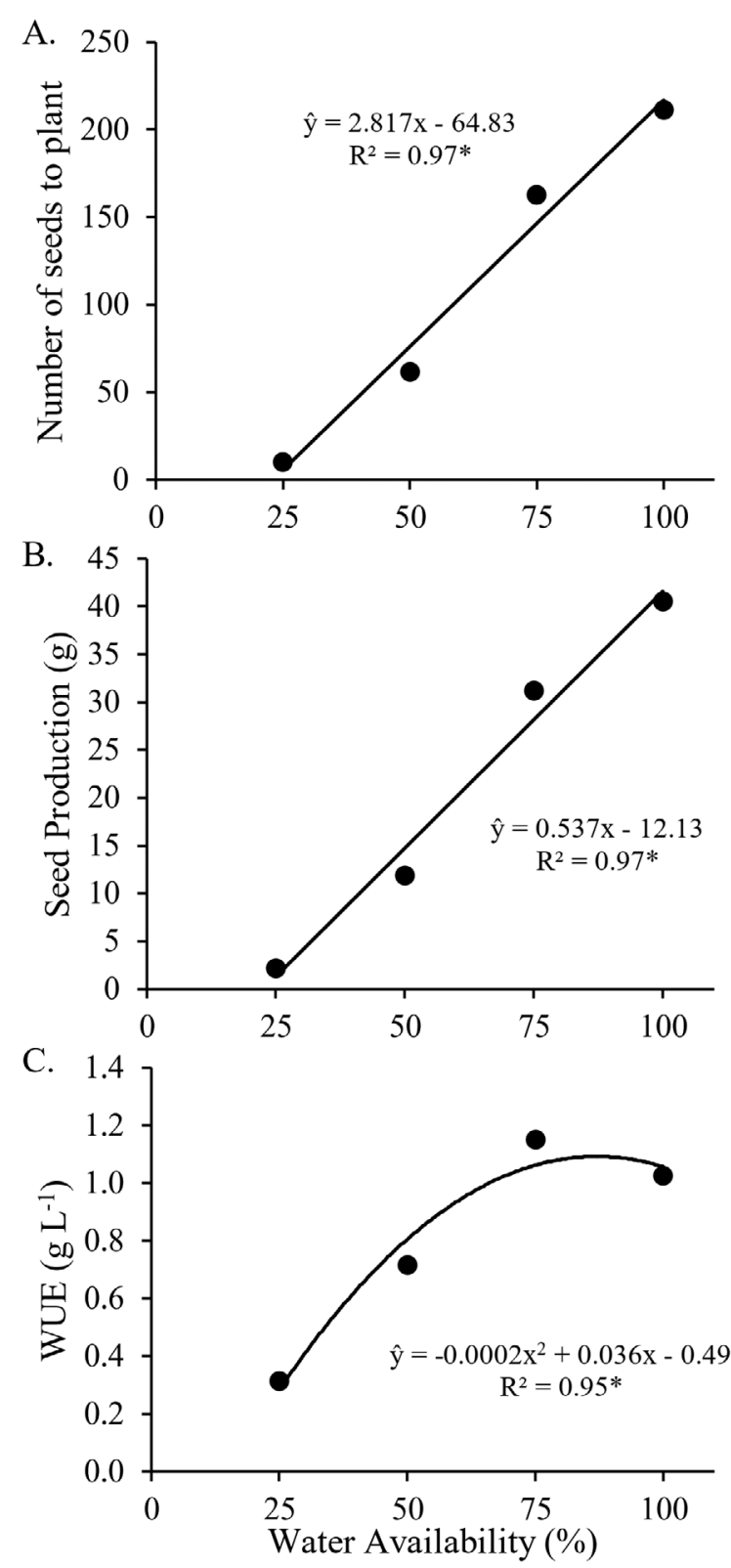

Significant regression coefficient with $\mathrm{p}<0.05(*)$.

Figure 2. Number of seeds to plant (A), Seed production (g) (B) and water use efficiency (WUE) $\left(\mathrm{g} \mathrm{L}^{-1}\right)(\mathrm{C})$ of cowpea, cultivar BRS Rouxinol, according to water availability and temperature 20-26-33 ${ }^{\circ} \mathrm{C}$.

conditions from cultivation without water deficiencies the water use efficiency is lower. This reduction in WUE was also reported by Souza et al. (2019) for cowpea irrigated applying
$50 \%$ of water demand compared to $100 \%$, reinforcing the water use efficiency can be obtained using less water in comparison to the water demand of the plant.

For the enzyme activities, was observed a significant interaction between water availability and temperature regime, except for GPX enzyme, which showed a significant difference only due to water availability (Table 3 ).

For the specific activity of each enzyme, it was observed a different behavior according to the temperature regimes. Higher CAT activities were observed with an increase of 4.8 ${ }^{\circ} \mathrm{C}$ in air temperature. The APX and SOD enzyme activities presented, in general, lower values in the high temperature regime. For GPX, there was no difference in the specific activity of this enzyme in the two temperature regimes (Figure 3).

It is possible to observe different behaviors of the activities of the enzymes evaluated with increased water availability in the evaluated temperature regimes. The plants submitted to the lower temperature regime showed an expected synchrony between the activities of the enzymes SOD, APX, CAT and GPX, with similar behaviors with the increase in water availability. It is possible to observe that the lower the water availability, the greater the SOD specific activity (first line of defense), as well as the enzymes that act in the second line of defense against oxidative stress (CAT, APX and GPX). Greater activity of antioxidant enzymes can contribute to a better tolerance to water deficit, increasing the protection against oxidative damage (Carvalho et al., 2019).

The synchrony of the behavior pattern of the SOD, APX, CAT and GPX enzymes is fundamental in the regulation of the level of ROS produced in the plant cell, since as the $\mathrm{O}_{2}{ }^{*}$ are generated, they are dismuted to $\mathrm{H}_{2} \mathrm{O}_{2}$ by the SOD and then, $\mathrm{H}_{2} \mathrm{O}_{2}$ is eliminated by the action of APX, CAT and GPX that converts it to water and oxygen (You \& Chan, 2015). Thus, the efficiency of this process reduces the level of oxidative stress, being considered crucial for the balance between the levels of $\mathrm{O}_{2}{ }^{-*}$ and $\mathrm{H}_{2} \mathrm{O}_{2}$ (Guimarães et al., 2018).

The plants submitted to cultivation with an increase of $4.8^{\circ} \mathrm{C}$, despite having, in general, lower values of enzymatic activity, did not show regression adjustments for the enzymes APX and CAT, as well as synchronization of the behavior with the activity of the SOD. This performance can be associated with the low adaptability of $\mathrm{cv}$. Rouxinol when submitted to thermal stress, given that it is recognized that high temperatures cause changes in the metabolism of a wide range of enzymes, which will reflect on the productive

Table 3. Summary of the variance analysis using the mean square for the values of Superoxide dismutase (SOD), Ascorbate peroxidase (APX), Catalase (CAT) and Guaiacol peroxidase (GPX), in cowpea plants cultivate Rouxinol, according to water availability and temperature regime in Brazil, 2018.

\begin{tabular}{lcccc}
\multicolumn{1}{c}{$\begin{array}{c}\text { Variation } \\
\text { source }\end{array}$} & SOD & APX & CAT & GPX \\
\cline { 2 - 5 } & $29.285^{* *}$ & $3301.284^{* *}$ & $1.481 \mathrm{~ns}$ & $12566.260^{* *}$ \\
Water availability (WA) & $298.852^{* *}$ & $13714.460^{* *}$ & $53.245^{* *}$ & $2173.380^{\text {ns }}$ \\
Temperature (T) & $10.448^{* *}$ & $3276.373^{* *}$ & $5.586^{*}$ & $2347.119^{\text {ns }}$ \\
WA $\times$ T & 17.17 & 28.68 & 12.78 & 30.25 \\
CV $(\%)$ & &
\end{tabular}

$\mathrm{DF}=$ degree of freedom; $\mathrm{CV}=$ coefficient of variation; $\mathrm{ns}=$ not significant, $* *$ significant at $1 \%$ of probability, ${ }^{*}$ significant at $5 \%$ of probability according to Tukey's test. 

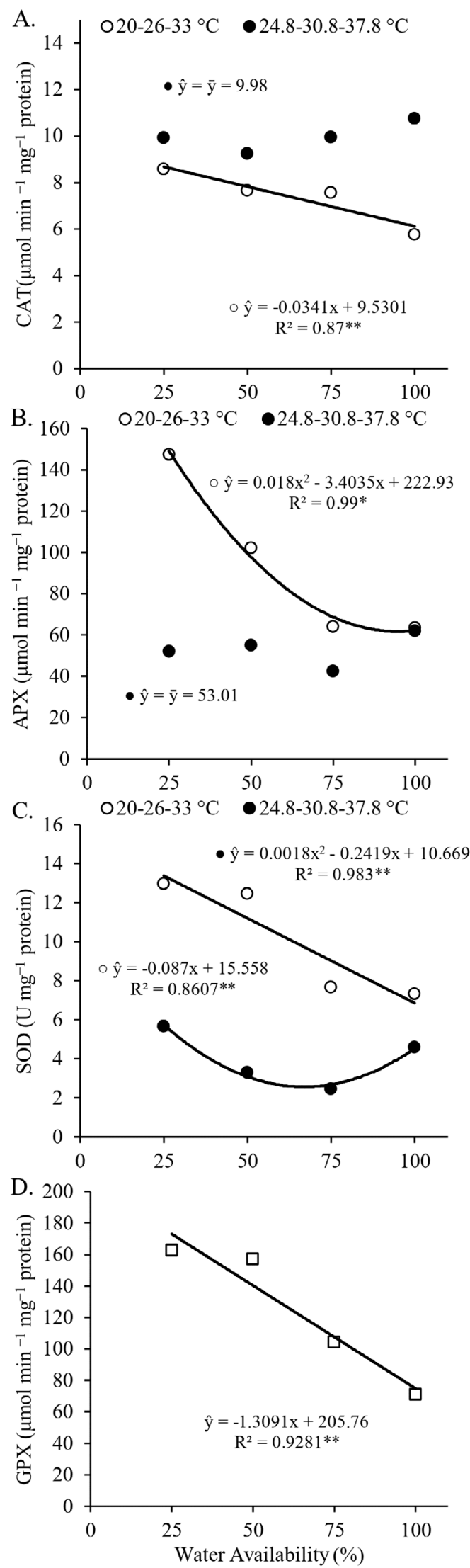

Figure 3. Specific enzyme activity, superoxide dismutase (SOD $\mathrm{U} \mathrm{mg}^{-1}$ protein), ascorbate peroxidase and catalase ( $\mu \mathrm{mol}$ $\mathrm{min}^{-1} \mathrm{mg}^{-1}$ protein) and guaiacol peroxidase ( $\mu \mathrm{mol} \mathrm{min}^{-1} \mathrm{mg}^{-1}$ protein) in cowpea bean plants cultivar Rouxinol, depending on water availability and temperature regime. parameters of plants, as observed in the results obtained in this present study.

Cowpea is an extremely important crop for the semiarid region. The results of our research may contribute to adjustments in management practices for the production of cowpea under climate changing scenarios. But the cultivar studied was sensitive to the applied stresses. Then, in future studies new cowpea cultivars with tolerance to water deficit and high temperature should be considered.

\section{Conclusion}

The cultivar Rouxinol was shown to be sensitive to an increase of $4.8^{\circ} \mathrm{C}$ in air temperature and to water deficit. However, even with $100 \%$ water availability, there was no seed production with an increase in air temperature. The increase in water availability provided an increase in the production of cowpea seeds in the temperature range $20-26-33{ }^{\circ} \mathrm{C}$, and the best water/grain conversion point occurs when plants are submitted to $90 \%$ of water availability. The increase of $4.8^{\circ} \mathrm{C}$ in air temperature promoted an increase in oxidative stress in cowpea plants cv. Rouxinol with lack of synchrony in the antioxidative defense system.

\section{Compliance with Ethical Standards}

Author contributions: Conceptualization: FA; Formal analysis: MJMG; Funding acquisition: FA; Investigation: JRAB; Methodology: FA; Project administration: FA; JRAB, RMS; Resources: FA; WLS, NFM; Supervision: FA; JRAB, WLS, NFM; Visualization: JRAB; Writing - original draft: JRAB; Writing review \& editing: FA; JRAB

Conflict of interest: The authors declare that they have no known competing financial interests or personal relationships that could have appeared to influence the work reported in this paper.

Funding: Fundação de Amparo à Pesquisa do Estado da Bahia - FAPESB (Grant No. N8 BOL0419/2017).

\section{Literature Cited}

Angelotti, F.; Barbosa, L. G.; Barros, J. R. A.; Santos, C. A. F dos. Cowpea (Vigna unguiculata) development under different temperatures and carbon dioxide concentrations. Revista Pesquisa Agropecuária Tropical, v. 50, n. 1, e59377, 2020. https:// doi.org/10.1590/1983-40632020v5059377.

Cakmak, I.; Horst, W. J. Effect of aluminium on lipid peroxidation, superoxide dismutase, catalase, and peroxidase activities in root tips of soybean (Glycine max). Physiologia Plantarum, v. 83, n. 3, p. 463-468, 1991. https://doi.org/10.1111/j.1399-3054.1991. tb00121.x.

Carvalho, M.; Castro, I.; Pereira, J. M.; Correia, C.; Cortines, M. E.; Matos, M.; Rosa, E.; Carnide, V.; Lino Neto, T. Evaluating stress responses in cowpea under drought stress. Journal of Plant Physiology, v. 241, n. 1, e153001, 2019. https://doi.org/10.1016/j. jplph.2019.153001. 
Cavalcanti, F. J de A. Recomendações de adubação para o estado de Pernambuco. 2a aproximação. 3.ed. Recife: IPA, 2008. 212 p.

Cunha, A. P. M. A.; Zeri, M., Deusdará, L. K.; Costa, L.; Cuartas, L. A.; Marengo, J. A.; Tomasella, J.; Vieira, R. M.; Barbosa, A. A.; Cunningham, C.; Cal, G. J. V.; Broedel, E.; Alvalá, R.; Ribeiro-Neto, G. Extreme drought events over Brazil from 2011 to 2019. Atmosphere, v. 10, n.1, e642, 2019. https://doi.org/10.3390/atmos10110642.

Fahad, S.; Bajwa, A. A.; Nazir, U.; Anjum, S. A.; Farooq, A.; Zohaib, A.; Sadia, S.; Nasim, W.; Adkins, S.; Saud, S.; Ihsan, M. Z.; Alharby, H.; Wu, C.; Wang, D.; Huang, J. Crop production under drought and heat stress: plant responses and management options. Frontiers in Plant Science, v. 8, n. 1, e01147, 2017. https://doi. org/10.3389/fpls.2017.01147.

Freire Filho, F. R.; Lima, J. A. A.; Ribeiro, V. Q. (Orgs). Feijãocaupi: avanços tecnológicos. Brasília: Embrapa Informações Tecnológicas, 2005. 519 p.

Giannopolitis, C. N.; Ries, S. K. Superoxide dismutases: I. Occurrence in higher plants. Plant Physiology, v. 59, n. 2, p. 309-314, 1977. https://doi.org/10.1104/pp.59.2.309.

Gray, S. B.; Brady, S.M. Plant developmental responses to climate change. Developmental Biology, v. 419, n. 1, p. 64-77, 2016. https://doi.org/10.1016/j.ydbio.2016.07.023.

Guimarães, M. J. M.; Simões, W. L.; Camara, T. J. R.; Silva, C. U. C.; Willadino, L. G. Antioxidant defenses of irrigated forage sorghum with saline aquaculture effluent. Revista Caatinga, v. 31, n. 1, p. 135142, 2018. https://doi.org/10.1590/1983-21252018v31n116rc.

Hatfield, J. L.; Boote, K. J.; Kimball, B. A.; Ziska, L. H.; Izaurralde, R. C.; Ort, D.; Thomson, A. M.; Wolfe, D. Climate impacts on agriculture: implications for crop production. Agronomy Journal, v. 103, n. 1, p. 351-370, 2011. https://doi.org/10.2134/agronj2010.0303.

Havir, E. A.; Mchale, N. A. Biochemical and developmental characterization of multiple forms of catalase in tobacco leaves. Plant Physiology, v. 84 , n. 2, p. 450-455, 1987. https://doi. org/10.1104/pp.84.2.450.

Intergovernmental Panel on Climate Change - IPCC. Climate change 2013: the physical science basis. Cambridge: University Press, 2013. 1535p.

Jumrani, K.; Bhatia, V. S. Impact of combined stress of high temperature and water deficit on growth and seed yield of soybean. Physiology and Molecular Biology of Plants, v. 24, n.1, p. 37-50, 2018. https://doi.org/10.1007/s12298-017-0480-5.

Koevoets, I. T.; Venema, J. H.; Elzenga, J. T.; Testerink, C. Roots withstanding their environment: exploiting root system architecture responses to abiotic stress to improve crop tolerance. Frontiers in Plant Science, v.7, e01335, 2016. https:// doi.org/10.3389/fpls.2016.01335.

Martinez, C. A.; Oliveira E. A. D.; Mello T. R. P.; Marin A. L. A. Respostas das plantas ao incremento atmosférico de dióxido de carbono e da temperatura. Revista Brasileira de Geografia Física, v.8, n.1 p. 635-650, 2015. https://doi.org/10.26848/rbgf.v8.0.p635-650.
Merwad, A. R. M. A.; Desoky, E. S. M.; Rady, M. M. Response of water deficit-stressed Vigna unguiculata performances to silicon, proline or methionine foliar application. Scientia Horticulturae, v. 228 , n. 1 , p. $132-144$, 2018. https://doi.org/10.1016/j. scienta.2017.10.

Mwale, S. E.; Mildred, O.S.; Kassim, S.; Achola, E.; Okul, V.; Gibson, P.; Edema, R.; Singini, P. G.; Rubaihayo, P. Response of cowpea genotypes to drought stress in Uganda. American Journal of Plant Sciences, v.8, n.4, p. 720-733, 2017. https://doi.org/10.4236/ ajps.2017.84050.

Nakano, Y.; Asada, K. Hydrogen peroxide is scavenged by ascorbate specific peroxidase in spinach chloroplast. Plant Cell Physiology, v. 22, n. 5, p. $867-880$, 1981. https://doi.org/10.1093/ oxfordjournals.pcp.a076232.

Ndiso, J. B.; Olubayo, F.; Chemining'wa, G. N.; Saha, H. M. Effect of drought stress on canopy temperature, growth and yield performance of cowpea varieties. International Journal of Plant \& Soil Science, v.9, n.3, e21844, 2016. https://doi.org/10.9734/ IJPSS/2016/21844.

Nielsen, C. L.; Hall, A. E. Responses of cowpea (Vigna unguiculata (L.) Walp.) in the field to high night air temperature during flowering. II. Plant responses. Field Crops Research, v.10, n.1, p. 181-1965, 1985. https://doi.org/10.1016/0378-4290(85)90025-5.

Oliveira, M. G. C.; Oliveira, L. F. C.; Wendland, A.; Guimarães, C. M.; Quintela, E. D.; Barbosa, F. R.; Carvalho, M. C. S.; Lobo Junior M.; Silveira, P. M. Conhecendo a fenologia do feijoeiro e seus aspectos fitotécnicos. Brasília: Embrapa Arroz e Feijão, 2018. 59 p.

Perdomo, J. A.; Conesa, M. À.; Medrano, H.; Ribas-Carbó, M.; Galmés, J. Effects of long-term individual and combined water and temperature stress on the growth of rice, wheat and maize: relationship with morphological and physiological acclimation. Physiology Plant, v.155, n. 1, p. 149-165, 2015. https://doi.org/10.1111/ppl.12303.

Souza, P. J. O. P.; Ramos, T. F.; Fiel, L. C. S.; Farias, V. D. S.; Sousa, D. P.; Nunes, H. G. G. C. Yield and water use efficiency of cowpea under water deficit. Revista Brasileira de Engenharia Agrícola e Ambiental, v.23, n.2, p.119-125, 2019. https://doi. org/10.1590/1807-1929/agriambi.v23n2p119-125.

Toscano, S.; Farieri, E.; Ferrante, A.; Romano, D. Physiological and biochemical responses in two ornamental shrubs to drought stress. Frontiers in Plant Science, v. 7, n. 1, e00645, 2016. https:// doi.org/10.3389/fpls.2016.00645.

$\mathrm{Xu}$, Z.; Jiang, Y.; Jia, B.; Zhou, G. Elevated- $\mathrm{CO}_{2}$ response of stomata and its dependence on environmental factors. Frontiers in Plant Science, v.7, n.1, e00657, 2016. https://doi.org/10.3389/ fpls.2016.00657.

You, J.; Chan, Z. ROS regulation during abiotic stress responses in crop plants. Frontiers in Plant Science, v. 6, n. 1, e01092, 2015. https://doi.org/10.3389/fpls.2015.01092. 